\title{
Synthesis and Crystal Structure of
}

\section{1-(4-Nitrobenzyl)-3-allyl-1H-benzo[d]imidazol-2(3H)-one}

\author{
Dounia Belaziz, ${ }^{1}$ Santiago V. Luis, ${ }^{2}$ Youssef Kandri Rodi, ${ }^{1}$ \\ Inés Martí, ${ }^{2}$ and Vicente Martí-Centelles ${ }^{2}$ \\ ${ }^{1}$ Laboratoire de Chimie Organique Appliquée, Faculté des Sciences et Techniques, Université Sidi Mohamed Ben Abdallah, Fès, Morocco \\ ${ }^{2}$ Universitat Jaume I, Departamento de Química Inorgánica y Orgánica, Avenida Sos Baynat, s/n, E-12071 Castellón, Spain
}

Correspondence should be addressed to Santiago V. Luis; luiss@qio.uji.es and Youssef Kandri Rodi; youssef_kandri_rodi@yahoo.fr

Received 29 May 2013; Accepted 2 July 2013

Academic Editor: Veysel T. Yilmaz

Copyright (C) 2013 Dounia Belaziz et al. This is an open access article distributed under the Creative Commons Attribution License, which permits unrestricted use, distribution, and reproduction in any medium, provided the original work is properly cited.

A functionalized benzimidazole, 1-(4-nitrobenzyl)-3-allyl-1H-benzo[d]imidazol-2(3H)-one, has been synthesized, and the crystal structure was determined and analyzed. This compound crystallizes in the monoclinic, space group $\mathrm{P} 2_{1} / \mathrm{n}$ (number 14$) c$ with cell parameters, $a=7.12148(8) \AA, b=16.12035(17) \AA, c=13.04169(17) \AA, \beta=93.3043(11), V=1494.71(3) \AA^{3}$, and $D_{\text {calc }}=$ $1.375 \mathrm{~g} / \mathrm{mm}^{3}$. The solid state geometry is stabilized by intermolecular $\pi-\pi$ interactions along with the van der Waals interactions which contribute to the stability of the crystal packing. Computational calculations have been used to properly understand the main intermolecular interactions present in the crystal.

\section{Introduction}

Functionalized benzimidazoles represent an important class of $\mathrm{N}$-containing heterocyclic compounds and have received considerable attention in recent times because of their applications as antiulcer, antihypertensive, antiviral, antifungal, anticancer, and antihistamine activities among others [1-5]. They are important intermediates in many organic reactions $[6,7]$ and act as ligands to transition metals for modelling biological systems $[8,9]$. In addition, the effectiveness of benzimidazoles in the treatment of diseases such as ischemiareperfusion injury [10], hypertension [11], and obesity [12] has been recently reported. Owing to their potential biological activities and other possible applications of the benzimidazoles, a clear need exists for developing synthetic strategies for the preparation of substituted benzimidazoles.

As a continuation of our research work devoted to the development of substituted benzimidazol-2-one derivatives [13-15], here we report on the synthesis of a new benzimidazol-2-one derivative displaying a new substitution pattern.
This compound has been obtained by the reaction of allylbromide (4) with 1-(4-nitrobenzyl)-1H-benzo[d]imidazol$2(3 \mathrm{H})$-one (3) in the presence of a catalytic quantity of tetran-butylammonium bromide under mild conditions providing the disubstituted compound (5) (Scheme 1).

\section{Materials and Methods}

To $1 \mathrm{H}$-benzo[d]imidazol-2(3H)-one (1) $(0.30 \mathrm{~g}, 2.24 \mathrm{mmol})$, potassium carbonate $(0.37 \mathrm{~g}, 2.68 \mathrm{mmol})$ and tetra-nbutylammonium bromide $(0.07 \mathrm{~g}, 0.22 \mathrm{mmol})$ in DMF $(20 \mathrm{~mL})$ were added to 4-nitro-benzylbromide (2) $(0.58 \mathrm{~g}$, $2.68 \mathrm{mmol}$ ). Stirring was continued at room temperature for 6 hours. The salt was removed by filtration and the filtrate concentrated under reduced pressure. The obtained compound (3) 1-(4-nitrobenzyl)-1H-benzo[d]imidazol$2(3 \mathrm{H})$-one was separated by chromatography on a column of silica gel with ethyl acetate/hexane $(1: 2)$ as eluent. The compound was recrystallized from ethanol to give colorless crystals (Scheme 2). 


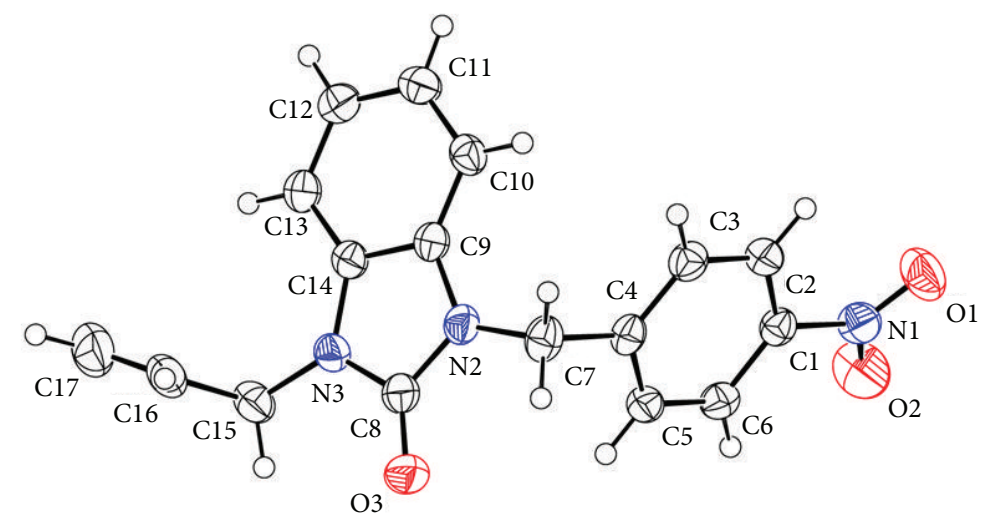

FIGURE 1: ORTEP representation of 5 (displacement ellipsoids are drawn at the $50 \%$ probability level).
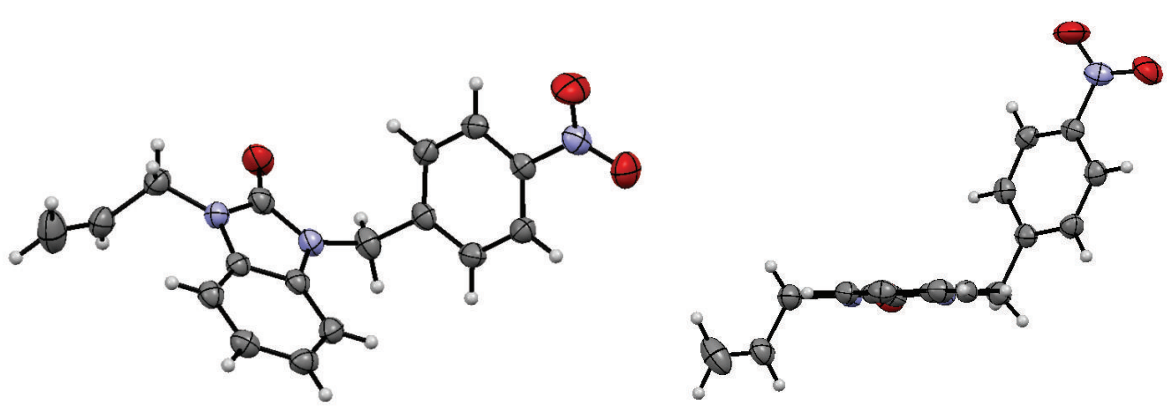

FIGURE 2: The unique molecule in the crystal structure of $\mathbf{5}$ (displacement ellipsoids are drawn at the $50 \%$ probability level).<smiles>C=CCn1c(=O)n(Cc2ccc([N+](=O)[O-])cc2)c2ccccc21</smiles>

(5)

SCHEMe 1

To the formerly obtained compound (3) (0.17 g, 0.63 $\mathrm{mmol})$ allylbromide $(4)(0.09 \mathrm{~g}, 0.76 \mathrm{mmol})$ in DMF $(10 \mathrm{~mL})$, potassium carbonate $(0.10 \mathrm{~g}, 0.76 \mathrm{mmol})$ and tetra-n-butylammonium bromide $(0.02 \mathrm{~g}, 0.063 \mathrm{mmol})$ were added (Scheme 3). Stirring was continued at room temperature for 12 hours. The salt was removed by filtration, and the filtrate concentrated under reduced pressure. The residue was separated by chromatography on a silica gel column with ethyl acetate/hexane $(1: 1)$ as the eluent. The obtained compound (5) was recrystallized from dichloromethane/hexane to give colorless crystals of 5 (melting point $=95^{\circ} \mathrm{C}$, yield $=87 \%$ ).

Single crystals of $\mathbf{5}$ were obtained from dichloromethane/hexane to give colorless crystals. A suitable crystal was selected and measured on an Agilent SuperNova Atlas
Dual Source, Agilent Technologies, diffractometer using the CrysAlisPro software. The crystal was kept at $200.00 \mathrm{~K}$ during data collection. Using Olex2 [16], the structure was solved with the ShelXS [17] structure solution program using direct methods and refined with the ShelXL [17] refinement package using least squares minimization. All hydrogen atoms were fixed in geometrical positions. Nonhydrogen atoms were refined with anisotropic displacement parameters. The molecular connectivity and the crystal packing diagram were drawn using the Mercury (CCDC) program [18] and PyMol [19]. Geometrical measurements were carried out using the Mercury (CCDC) program [18].

Crystal Data for $5 \mathrm{C}_{17} \mathrm{H}_{15} \mathrm{~N}_{3} \mathrm{O}_{3}(M=309.32)$ : monoclinic, space group $\mathrm{P} 2 / \mathrm{n}$ (no. 14 ), $a=7.12148(8) \AA, b$ $=16.12035(17) \AA, c=13.04169(17) \AA, \beta=93.3043(11), V$ $=1494.71(3) \AA^{3}, Z=4, T=200.00(10) \mathrm{K}, \mu(\mathrm{Cu} \mathrm{K} \alpha)=$ $0.795 \mathrm{~mm}^{-1}, D_{\text {calc }}=1.375 \mathrm{~g} / \mathrm{mm}^{3}, 14200$ reflections measured $(8.74 \leq 2 \Theta \leq 146.06), 2935$ unique $\left(R_{\text {int }}=0.0215\right)$ which were used in all calculations. The final $R_{1}$ was 0.0353 ( $>2$ sigma(I)), and $w R_{2}$ was 0.0962 (all data). CCDC number 948080 . See Figure 1 for the ORTEP representation of 5 .

In order to obtain an additional insight into the intermolecular forces determining the crystal packing, computational calculations were used for the optimization of the molecule and the calculation of the energies associated to the different intermolecular interactions at the PM3 level of calculation using the Spartan'08 software [20]. 


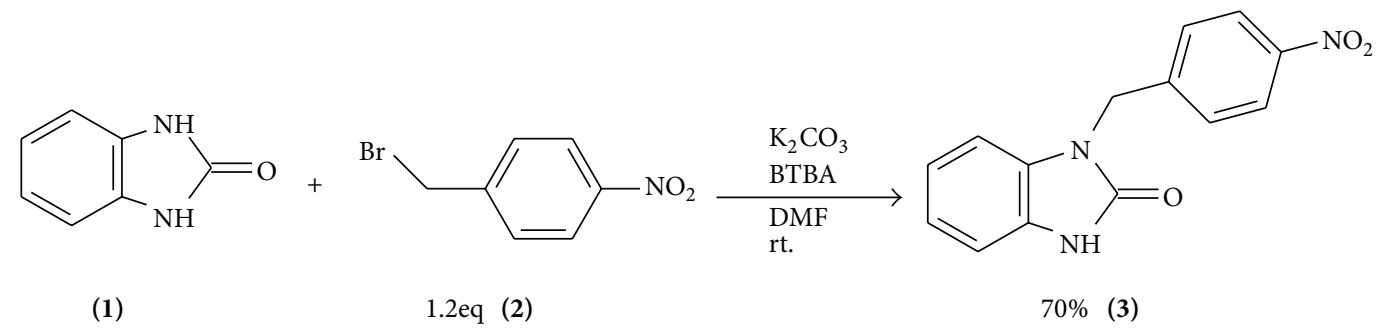

SCHEME 2

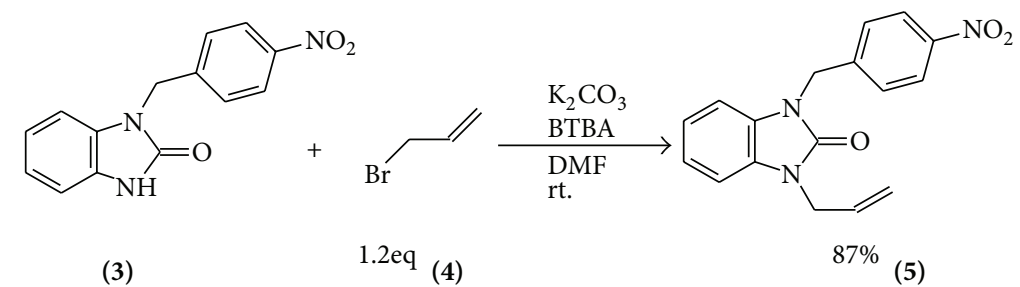

SCHeme 3

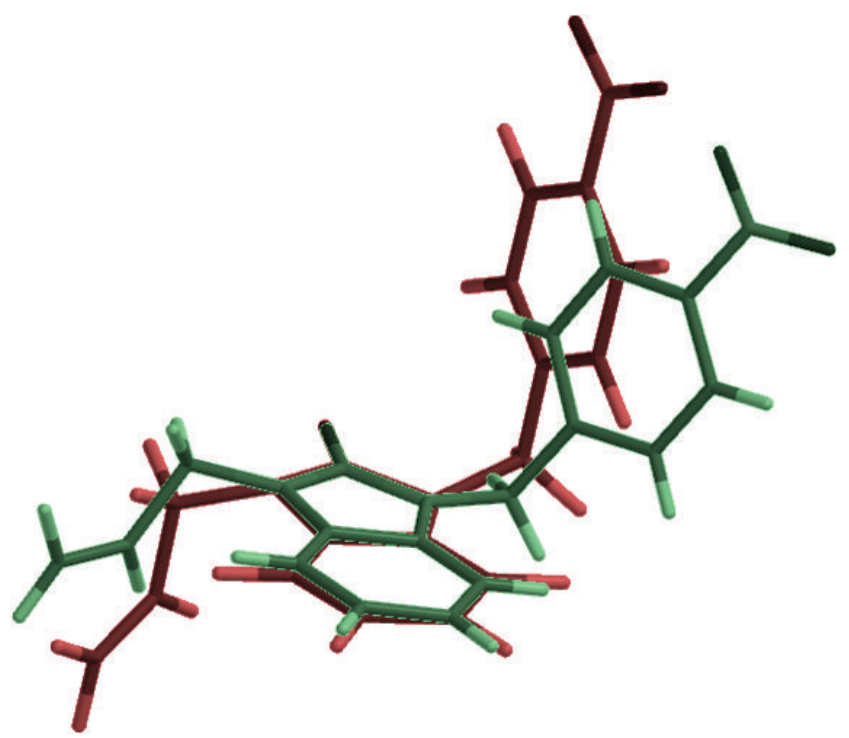

Figure 3: Superimposed structures: optimized at PM3: red; X-ray: green.

\section{Results and Discussion}

The details of the crystal data, data collection, and structure refinements are shown in Table 1 and the unique molecule in the crystal structure of $\mathbf{5}$ in Figure 2.

The title compound $\mathrm{C}_{17} \mathrm{H}_{15} \mathrm{~N}_{3} \mathrm{O}_{3}$ is a new heterocyclic system deriving from $1 \mathrm{H}$-benzo[d]imidazol-2 $(3 \mathrm{H})$-one. The crystal structure of this molecule is formed by two fused six- and five-membered rings linked to one benzyl and one allyl groups. The fused-ring system is fundamentally planar, with the maximum deviation from the mean plane of 0.010 (6) $\AA$ for N3. The benzyl and allyl groups are almost perpendicular to the benzimidazole plane but oriented in opposite directions (Figure 2).
TABLE 1: Crystal data and structure refinement for $\mathbf{5}$.

\begin{tabular}{|c|c|}
\hline Empirical formula & $\mathrm{C}_{17} \mathrm{H}_{15} \mathrm{~N}_{3} \mathrm{O}_{3}$ \\
\hline Formula weight & 309.32 \\
\hline Temperature/K & $200.00(10)$ \\
\hline Crystal system & Monoclinic \\
\hline Space group & $\mathrm{P} 2_{1} / \mathrm{n}$ \\
\hline$a / \AA$ & $7.12148(8)$ \\
\hline$b / \AA$ & $16.12035(17)$ \\
\hline$c / \AA$ & $13.04169(17)$ \\
\hline$\alpha /^{\circ}$ & 90.00 \\
\hline$\beta 1^{\circ}$ & $93.3043(11)$ \\
\hline$\gamma /^{\circ}$ & 90.00 \\
\hline Volume $/ \AA^{3}$ & $1494.71(3)$ \\
\hline$Z$ & 4 \\
\hline$D_{\text {calc }} / \mathrm{mg} / \mathrm{mm}^{3}$ & 1.375 \\
\hline $\mathrm{m} / \mathrm{mm}^{-1}$ & 0.795 \\
\hline$F(000)$ & 648.0 \\
\hline Crystal size $/ \mathrm{mm}^{3}$ & $0.225 \times 0.1759 \times 0.07$ \\
\hline $2 \Theta$ range for data collection & 8.74 to 146.06 \\
\hline Index ranges & $\begin{array}{l}-8 \leq h \leq 8,-20 \leq k \leq 19,-13 \\
\leq l \leq 16\end{array}$ \\
\hline Reflections collected & 14200 \\
\hline Independent reflections & $2935[R($ int $)=0.0215]$ \\
\hline Data/restraints/parameters & $2935 / 0 / 216$ \\
\hline Goodness-of-fit on $F^{2}$ & 1.070 \\
\hline Final $R$ indexes $[I \geq 2 \sigma(I)]$ & $R_{1}=0.0353, w R_{2}=0.0930$ \\
\hline Final $R$ indexes [all data] & $R_{1}=0.0394, w R_{2}=0.0962$ \\
\hline Largest diff. peak/hole/e $\AA^{-3}$ & $0.18 /-0.23$ \\
\hline
\end{tabular}

The theoretical PM3 calculations, after geometrical optimization of the molecule, reveal torsion angles, and these 

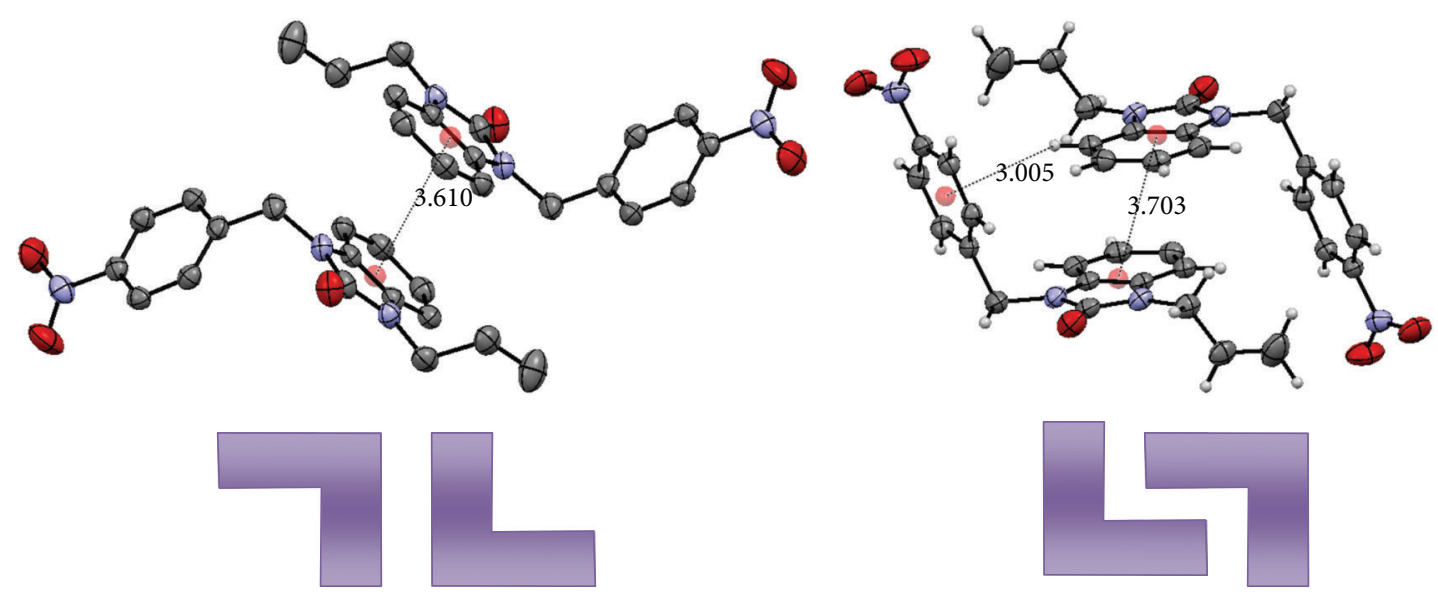

Figure 4: Intermolecular 1H-benzo[d]imidazol-2(3H)-one-1H-benzo[d]imidazol-2(3H)-one $\pi-\pi$ interactions.
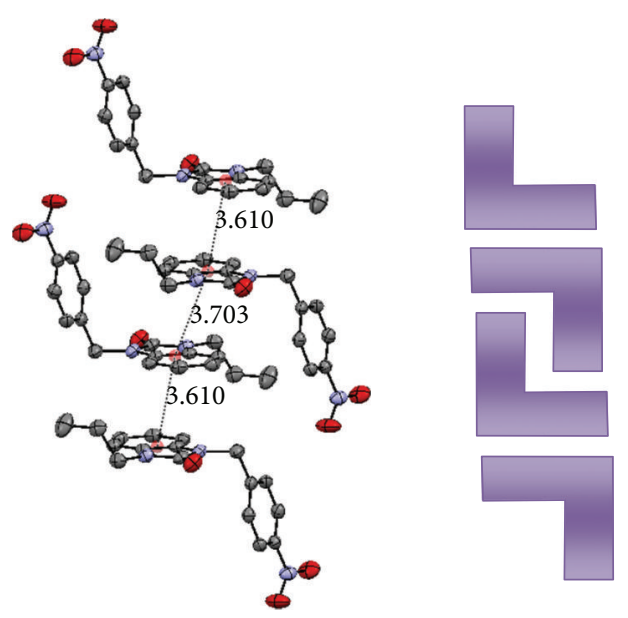

FIGURE 5: Arrays formed by intermolecular 1H-benzo[d]imidazol$2(3 \mathrm{H})$-one- $1 \mathrm{H}$-benzo[d]imidazol-2(3H)-one $\pi-\pi$ interactions.

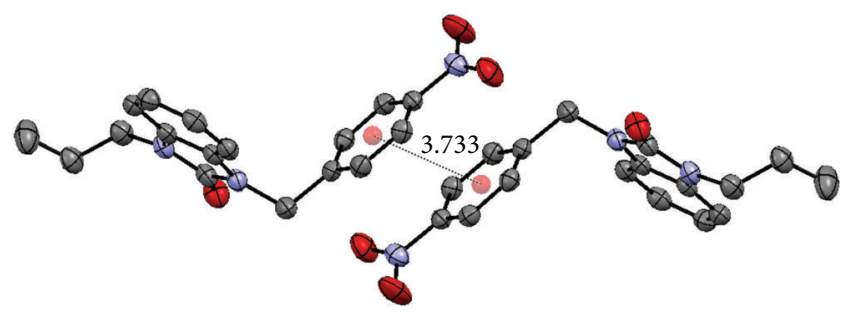

FIGURE 6: Intermolecular $\pi-\pi$ interactions.

have been compared with the experimental values. The torsion angles of the $1 \mathrm{H}$-benzo[d]imidazol-2(3H)-one substituents of the calculated geometry differ significantly from the ones obtained in the solid state structure (Figure 2). The $\mathrm{C} 4-\mathrm{C} 7-\mathrm{N} 2-\mathrm{C} 8$ angle changes from $106.83(12)^{\circ}$ in the solid state to $72.46^{\circ}$ in the optimized geometry. A similar trend is found for the $\mathrm{C} 16-\mathrm{C} 15-\mathrm{N} 3-\mathrm{C} 8$ that has a value of $111.84(13)^{\circ}$ in the solid state and $72.56^{\circ}$ in the optimized geometry. The variations in the bond angle are not as important: N2C7-C4 that has a value of 111.52(10) in the solid state and

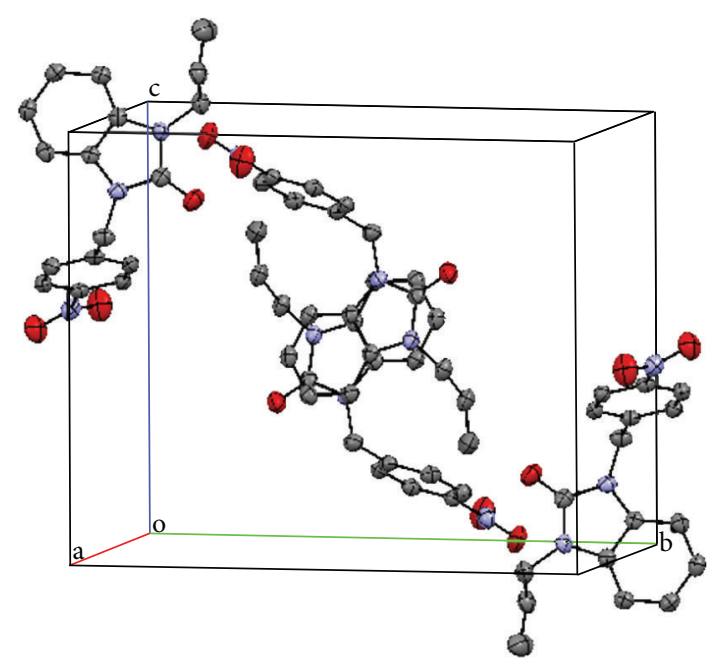

FIGURE 7: Molecular packing in the unit cell showing four molecules in the asymmetric unit.

$114.44^{\circ}$ in the optimized geometry, N3-C15-C16 that has a value of $112.65(10)$ in the solid state and $113.91^{\circ}$ in the optimized geometry. These results suggest that the change in the conformation of the molecule will be stabilized by the formation of intermolecular interactions in the crystal structure overcoming the unfavorable conformational changes in the substituents, Figure 3.

An analysis of the crystal packing shows the presence of intermolecular $\pi-\pi$ interactions between the $1 \mathrm{H}$ benzo[d]imidazol-2(3H)-one rings. Two of those interactions can be observed; in one of them, the two molecules displaying an $\mathrm{L}$ shape are oriented in an antiparallel arrangement, while in the second one, both molecules adopt a complementary disposition one siting over the other, Figure 4. In this second case, the benzene moiety of the benzoimidazole ring of one molecule is pointing towards the nitrobenzene fragment of the second molecule with an $\mathrm{H}$-centroid distance of $3.005 \AA$; a new $\mathrm{H}-\pi$ interaction is formed stabilizing the formation of such dimeric units. These main interactions that 

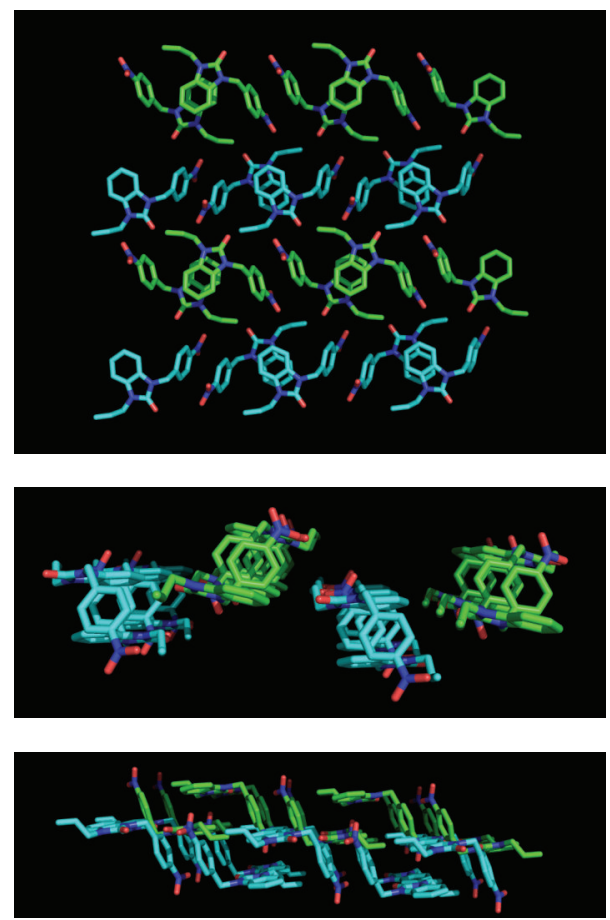

FIGURE 8: Observed arrays of parallel aromatic units involving nitrobenzene-nitrobenzene interactions (bc plane) highlighted in green and cyan.
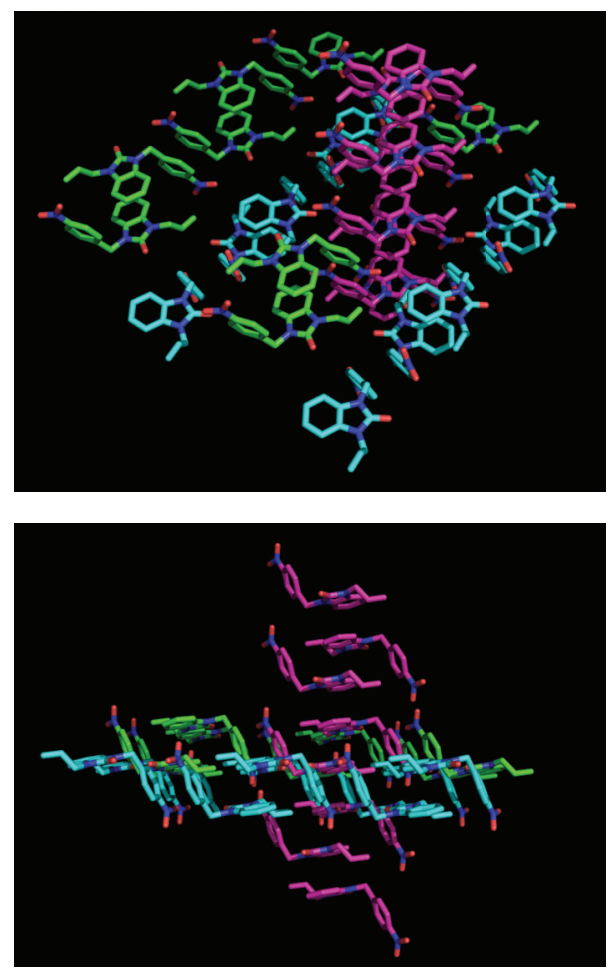

FIGURE 9: Observed arrays (based on nitrobenzene-nitrobenzene interactions) highlighted in green and cyan in the bc plane and in the a direction in magenta (formed by $1 \mathrm{H}$-benzo[d]imidazol-2(3H)one-1H-benzo[d]imidazol-2(3H)-on $\pi-\pi$ interactions).
TABLE 2: Bond lengths for 5 .

\begin{tabular}{|c|c|}
\hline Length $(\AA)$ & \\
\hline $\mathrm{C} 1-\mathrm{C} 2$ & $1.3810(16)$ \\
\hline $\mathrm{C} 1-\mathrm{C} 6$ & $1.3835(16)$ \\
\hline $\mathrm{C} 1-\mathrm{N} 1$ & $1.4653(15)$ \\
\hline $\mathrm{C} 2-\mathrm{C} 3$ & $1.3855(17)$ \\
\hline C3-C4 & $1.3894(17)$ \\
\hline C4-C5 & $1.3928(16)$ \\
\hline $\mathrm{C} 4-\mathrm{C} 7$ & $1.5147(16)$ \\
\hline C5-C6 & $1.3815(16)$ \\
\hline $\mathrm{C} 7-\mathrm{N} 2$ & $1.4534(16)$ \\
\hline $\mathrm{C} 8-\mathrm{N} 2$ & $1.3809(15)$ \\
\hline $\mathrm{C} 8-\mathrm{N} 3$ & $1.3778(17)$ \\
\hline $\mathrm{C} 8-\mathrm{O} 3$ & $1.2255(15)$ \\
\hline C9-C10 & $1.3809(16)$ \\
\hline C9-C14 & $1.3974(17)$ \\
\hline $\mathrm{C} 9-\mathrm{N} 2$ & $1.3885(15)$ \\
\hline C10-C11 & $1.3908(18)$ \\
\hline $\mathrm{C} 11-\mathrm{C} 12$ & $1.3869(19)$ \\
\hline $\mathrm{C} 12-\mathrm{C} 13$ & $1.3923(17)$ \\
\hline $\mathrm{C} 13-\mathrm{C} 14$ & $1.3801(17)$ \\
\hline C14-N3 & $1.3898(14)$ \\
\hline $\mathrm{C} 15-\mathrm{C} 16$ & $1.4959(18)$ \\
\hline C15-N3 & $1.4551(15)$ \\
\hline $\mathrm{C} 16-\mathrm{C} 17$ & $1.306(2)$ \\
\hline N1-O1 & $1.2241(15)$ \\
\hline N1-O2 & $1.2182(15)$ \\
\hline
\end{tabular}

held together the molecules of $\mathbf{5}$ have $3.610 \AA$ and $3.703 \AA$ centroid-centroid distances; see Figures 4 and 5. These directional interactions yield to the formation of ordered arrays of parallel $1 \mathrm{H}$-benzo[d]imidazol-2(3H)-one.

Intermolecular $\pi-\pi$ interactions between the nitrobenzene substituents are also found in the crystal structure, having a $3.733 \AA$ centroid-centroid distance, Figure 6. The position of the molecules in the asymmetric unit is depicted in Figure 7.

Thus, this arrangement generates parallel arrays of nitrobenzene rings ( $b c$ plane) that are held together by $\pi-\pi$ interactions (Figure 8), along with arrays of parallel benzimidazole fragments in the $a$ direction also based on $\pi-\pi$ interactions (Figure 9).

Computational studies at a semiempirical level of theory PM3 (from X-ray geometries without optimization at PM3 level of theory) allow obtaining the relative stability of the different $\pi-\pi$ interactions observed in the solid state structure (Figure 10). For this purpose, the relative energy of the dimers displayed in Figure 10, each one containing one of such intermolecular interactions, except the first one containing two, was calculated with all the distances and angles fixed according to the X-ray structure. Thus, calculations predict that the $1 \mathrm{H}$-benzo[d]imidazol-2(3H)-one$1 \mathrm{H}$-benzo[d]imidazol-2(3H)-one $\pi-\pi$ interaction is more 

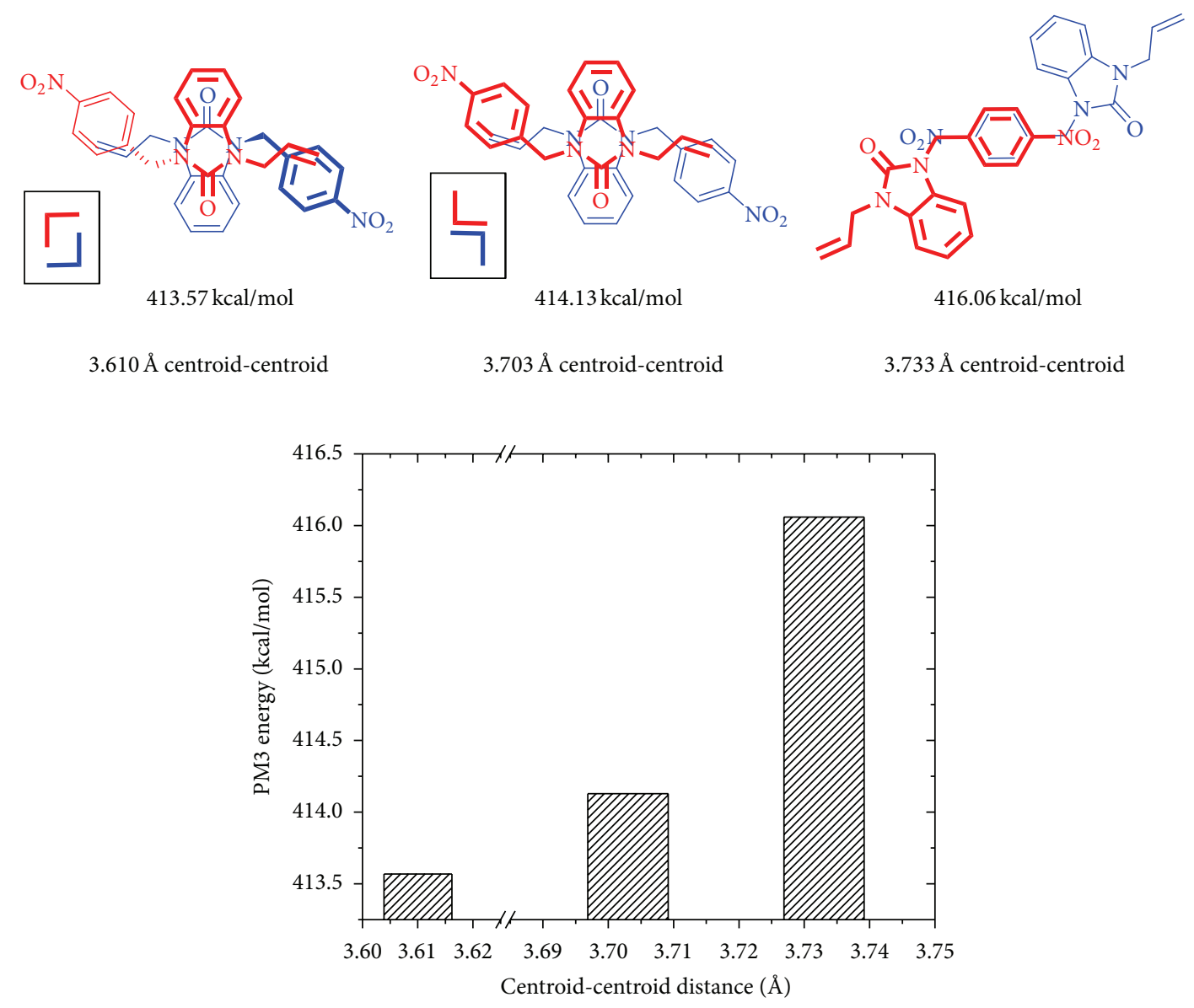

Figure 10: Calculated energy for the dimers observed at the X-ray crystal structure.

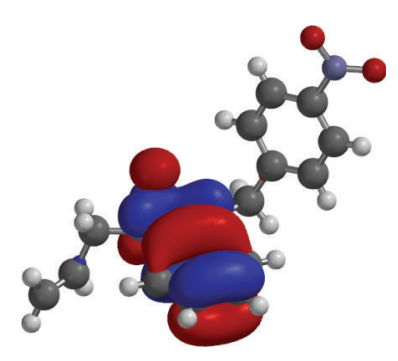

HOMO

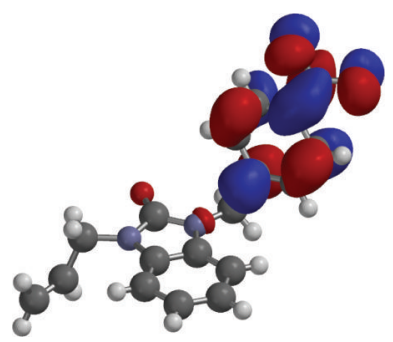

LUMO

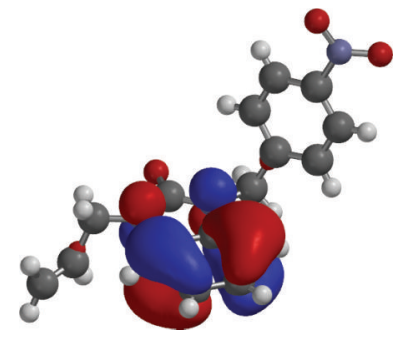

HOMO - 1

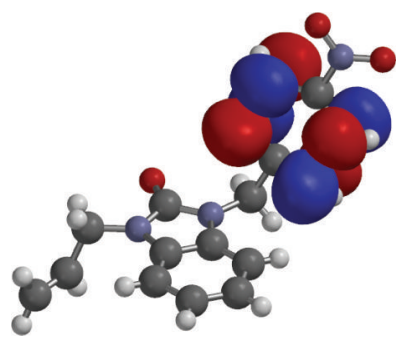

$\mathrm{LUMO}+1$

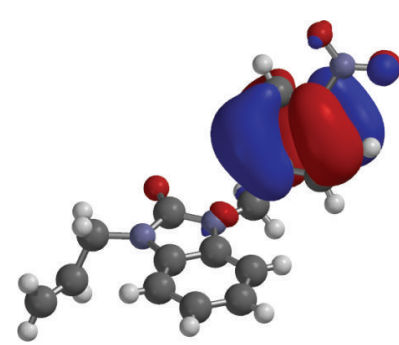

HOMO - 2

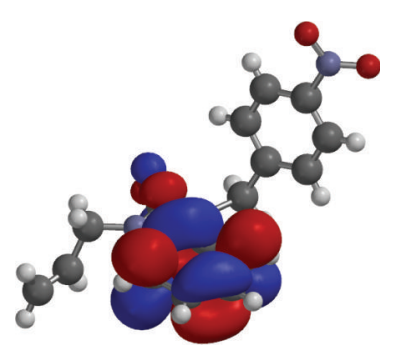

$\mathrm{LUMO}+2$

Figure 11: Frontier orbitals. HF/3-21G* from X-ray geometry. 
TABLE 3: Bond angles for 5

\begin{tabular}{|c|c|}
\hline Angle $\left(^{\circ}\right)$ & \\
\hline $\mathrm{C} 2-\mathrm{C} 1-\mathrm{C} 6$ & $122.80(11)$ \\
\hline $\mathrm{C} 2-\mathrm{C} 1-\mathrm{N} 1$ & $118.25(10)$ \\
\hline C6-C1-N1 & $118.92(10)$ \\
\hline $\mathrm{C} 1-\mathrm{C} 2-\mathrm{C} 3$ & $118.24(11)$ \\
\hline $\mathrm{C} 2-\mathrm{C} 3-\mathrm{C} 4$ & $120.66(11)$ \\
\hline C3-C4-C5 & $119.33(10)$ \\
\hline $\mathrm{C} 3-\mathrm{C} 4-\mathrm{C} 7$ & $120.98(11)$ \\
\hline C5-C4-C7 & $119.67(11)$ \\
\hline C6-C5-C4 & 121.07(11) \\
\hline C5-C6-C1 & $117.88(10)$ \\
\hline N2-C7-C4 & $111.52(10)$ \\
\hline N3-C8-N2 & $106.21(10)$ \\
\hline $\mathrm{O} 3-\mathrm{C} 8-\mathrm{N} 2$ & $126.65(12)$ \\
\hline $\mathrm{O} 3-\mathrm{C} 8-\mathrm{N} 3$ & $127.14(12)$ \\
\hline C10-C9-C14 & 121.51(11) \\
\hline $\mathrm{C} 10-\mathrm{C} 9-\mathrm{N} 2$ & 131.52(11) \\
\hline N2-C9-C14 & $106.97(10)$ \\
\hline C9-C10-C11 & $117.10(11)$ \\
\hline C12-C11-C10 & $121.32(11)$ \\
\hline $\mathrm{C} 11-\mathrm{C} 12-\mathrm{C} 13$ & $121.63(12)$ \\
\hline $\mathrm{C} 14-\mathrm{C} 13-\mathrm{C} 12$ & $116.94(11)$ \\
\hline C13-C14-C9 & $121.49(11)$ \\
\hline $\mathrm{C} 13-\mathrm{C} 14-\mathrm{N} 3$ & 131.63(11) \\
\hline N3-C14-C9 & $106.88(10)$ \\
\hline N3-C15-C16 & $112.65(10)$ \\
\hline C17-C16-C15 & $124.92(15)$ \\
\hline O1-N1-C1 & $118.32(10)$ \\
\hline $\mathrm{O} 2-\mathrm{N} 1-\mathrm{C} 1$ & $118.49(11)$ \\
\hline $\mathrm{O} 2-\mathrm{N} 1-\mathrm{O} 1$ & 123.18(11) \\
\hline $\mathrm{C} 8-\mathrm{N} 2-\mathrm{C} 7$ & $123.76(10)$ \\
\hline $\mathrm{C} 8-\mathrm{N} 2-\mathrm{C} 9$ & $109.93(10)$ \\
\hline C9-N2-C7 & $126.31(10)$ \\
\hline C8-N3-C14 & $110.02(10)$ \\
\hline C8-N3-C15 & $123.80(10)$ \\
\hline C14-N3-C15 & $126.18(10)$ \\
\hline
\end{tabular}

stable than the nitrobenzene-nitrobenzene $\pi-\pi$ interaction. The energy difference between the dimmers 1 and 3 is $2.49 \mathrm{kcal} / \mathrm{mol}$, although it must be taken into consideration that in the case of the first dimer, a second edge to face interaction between the benzimidazole and the nitrobenzene fragments is also present. The difference in calculated energy between 2 and 3 is $1.93 \mathrm{kcal} / \mathrm{mol}$.

The HOMO and LUMO -2 are located on the $1 \mathrm{H}$ benzo[d]imidazol-2(3H)-one moiety and the LUMO and $\mathrm{HOMO}+2$ on the nitrobenzene ring, and therefore, the interaction between these frontier orbitals is the responsible of the observed $\pi-\pi$ interactions, Figure 11 .

Tables 2, 3, and 4 summarize all bond lengths, bond angles, and torsion angles obtained for the X-ray crystal structure of 5 .
TABLE 4: Torsion angles for $\mathbf{5}$.

\begin{tabular}{|c|c|}
\hline Dihedral $\left(^{\circ}\right)$ & \\
\hline $\mathrm{C} 1-\mathrm{C} 2-\mathrm{C} 3-\mathrm{C} 4$ & $1.02(18)$ \\
\hline $\mathrm{C} 2-\mathrm{C} 1-\mathrm{C} 6-\mathrm{C} 5$ & $-0.42(17)$ \\
\hline C2-C1-N1-O1 & 19.16(16) \\
\hline $\mathrm{C} 2-\mathrm{C} 1-\mathrm{N} 1-\mathrm{O} 2$ & $-162.30(12)$ \\
\hline $\mathrm{C} 2-\mathrm{C} 3-\mathrm{C} 4-\mathrm{C} 5$ & $-0.22(18)$ \\
\hline $\mathrm{C} 2-\mathrm{C} 3-\mathrm{C} 4-\mathrm{C} 7$ & $-178.68(11)$ \\
\hline C3-C4-C5-C6 & $-0.94(17)$ \\
\hline $\mathrm{C} 3-\mathrm{C} 4-\mathrm{C} 7-\mathrm{N} 2$ & $108.96(13)$ \\
\hline $\mathrm{C} 4-\mathrm{C} 5-\mathrm{C} 6-\mathrm{C} 1$ & $1.24(17)$ \\
\hline $\mathrm{C} 4-\mathrm{C} 7-\mathrm{N} 2-\mathrm{C} 8$ & $106.83(12)$ \\
\hline $\mathrm{C} 4-\mathrm{C} 7-\mathrm{N} 2-\mathrm{C} 9$ & $-73.63(14)$ \\
\hline $\mathrm{C} 5-\mathrm{C} 4-\mathrm{C} 7-\mathrm{N} 2$ & $-69.49(14)$ \\
\hline $\mathrm{C} 6-\mathrm{C} 1-\mathrm{C} 2-\mathrm{C} 3$ & $-0.70(18)$ \\
\hline C6-C1-N1-O1 & $-159.22(12)$ \\
\hline C6-C1-N1-O2 & 19.32(17) \\
\hline C7-C4-C5-C6 & $177.54(11)$ \\
\hline C9-C10-C11-C12 & $-0.59(17)$ \\
\hline C9-C14-N3-C8 & $-0.49(12)$ \\
\hline C9-C14-N3-C15 & $-179.71(10)$ \\
\hline C10-C9-C14-C13 & $0.87(16)$ \\
\hline C10-C9-C14-N3 & $-179.18(10)$ \\
\hline C10-C9-N2-C7 & $-0.25(19)$ \\
\hline C10-C9-N2-C8 & $179.34(11)$ \\
\hline $\mathrm{C} 10-\mathrm{C} 11-\mathrm{C} 12-\mathrm{C} 13$ & $0.57(18)$ \\
\hline $\mathrm{C} 11-\mathrm{C} 12-\mathrm{C} 13-\mathrm{C} 14$ & $0.17(17)$ \\
\hline $\mathrm{C} 12-\mathrm{C} 13-\mathrm{C} 14-\mathrm{C} 9$ & $-0.87(16)$ \\
\hline C12-C13-C14-N3 & $179.20(11)$ \\
\hline C13-C14-N3-C8 & $179.44(11)$ \\
\hline C13-C14-N3-C15 & $0.23(18)$ \\
\hline C14-C9-C10-C11 & $-0.12(16)$ \\
\hline C14-C9-N2-C7 & $-179.80(10)$ \\
\hline C14-C9-N2-C8 & $-0.21(12)$ \\
\hline C16-C15-N3-C8 & $111.84(13)$ \\
\hline C16-C15-N3-C14 & $-69.05(15)$ \\
\hline N1-C1-C2-C3 & $-179.02(10)$ \\
\hline N1-C1-C6-C5 & $177.89(10)$ \\
\hline N2-C8-N3-C14 & $0.37(12)$ \\
\hline N2-C8-N3-C15 & $179.60(10)$ \\
\hline N2-C9-C10-C11 & $-179.61(11)$ \\
\hline N2-C9-C14-C13 & $-179.52(10)$ \\
\hline N2-C9-C14-N3 & $0.42(11)$ \\
\hline N3-C8-N2-C7 & $179.51(10)$ \\
\hline N3-C8-N2-C9 & $-0.09(12)$ \\
\hline N3-C15-C16-C17 & $127.76(15)$ \\
\hline $\mathrm{O} 3-\mathrm{C} 8-\mathrm{N} 2-\mathrm{C} 7$ & $-0.37(19)$ \\
\hline $\mathrm{O} 3-\mathrm{C} 8-\mathrm{N} 2-\mathrm{C} 9$ & $-179.98(11)$ \\
\hline $\mathrm{O} 3-\mathrm{C} 8-\mathrm{N} 3-\mathrm{C} 14$ & $-179.75(11)$ \\
\hline O3-C8-N3-C15 & $-0.51(19)$ \\
\hline
\end{tabular}

\section{Conclusions}

A new substituted benzo[d]imidazole-2 $(3 \mathrm{H})$-one has been synthesized (1-(4-nitrobenzyl)-3-allyl-1H-benzo[d]imidazol$2(3 \mathrm{H})$-one), and its crystal structure has been determined, showing a solid state geometry stabilized by intermolecular $\pi-\pi$ interactions, benzimidazole-benzimidazole, and nitrobenzene-nitrobenzene providing the formation of a stable three-dimensional network. Computational calculations 
have allowed a better understanding of the nature of those intermolecular interactions present in the crystal structure.

\section{Acknowledgments}

Financial support has been provided by GV (PROMETEO/2012/020) and MINECO (CTQ2012-38543-C03-01).

\section{References}

[1] P. W. Erhardt, "In search of the digitalis replacement," Journal of Medicinal Chemistry, vol. 30, no. 2, pp. 231-237, 1987.

[2] G. L. Gravalt, B. C. Baguley, W. R. Wilson, and W. A. Denny, "DNA-directed alkylating agents. 6. Synthesis and antitumor activity of DNA minor groove-targeted aniline mustard analogs of pibenzimol (Hoechst 33258)," Journal of Medical Chemistry, vol. 37, pp. 4338-4345, 1994.

[3] K.-J. Soderlind, B. Gorodetsky, A. K. Singh, N. R. Bachur, G. G. Miller, and J. W. Lown, "Bis-benzimidazole anticancer agents: targeting human tumour helicases," Anti-Cancer Drug Design, vol. 14, no. 1, pp. 19-25, 1999.

[4] J. S. Kim, B. Gatto, C. Yu, A. Liu, L. F. Liu, and E. J. LaVoie, "Substituted 2,5'-Bi-1H-benzimidazoles: topoisoraerase I inhibition and cytotoxicity," Journal of Medicinal Chemistry, vol. 39, no. 4, pp. 992-998, 1996.

[5] T. Roth, M. L. Morningstar, P. L. Boyer, S. H. Hughes, R. W. Buckheit Jr., and C. J. Michejda, "Synthesis and biological activity of novel nonnucleoside inhibitors of HIV-1 reverse transcriptase. 2-Aryl-substituted benzimidazoles," Journal of Medicinal Chemistry, vol. 40, no. 26, pp. 4199-4207, 1997.

[6] Y. Bai, J. Lu, Z. Shi, and B. Yang, "Synthesis of 2,15hexadecanedione as a precursor of muscone," Synlett, vol. 12, no. 4, pp. 544-546, 2001.

[7] E. Hasegawa, A. Yoneoka, K. Suzuki, T. Kato, T. Kitazume, and $\mathrm{K}$. Yanagi, "Reductive transformation of $\alpha \beta$-epoxy ketones and other compounds promoted through photoinduced electron transfer processes with 1,3-dimethyl- 2-phenylbenzimidazoline (DMPBI)," Tetrahedron, vol. 55, no. 45, pp. 12957-12968, 1999.

[8] E. Bouwman, W. L. Driessen, and J. Reedjik, "Model systems for type I copper proteins: structures of copper coordination compounds with thioether and azole-containing ligands," Coordination Chemistry Reviews, vol. 104, no. 1, pp. 143-172, 1990.

[9] M. A. Pujar, T. D. Bharamgoudar, and D. N. Sathyanarayana, "Cobalt(II), nickel(II) and copper(II) complexes of bidentate bibenzimidazoles," Transition Metal Chemistry, vol. 13, no. 6, pp. 423-425, 1988.

[10] G.-D. Zhu, V. B. Gandhi, J. Gong et al., "Synthesis and SAR of novel, potent and orally bioavailable benzimidazole inhibitors of poly(ADP-ribose) polymerase (PARP) with a quaternary methylene-amino substituent," Bioorganic and Medicinal Chemistry Letters, vol. 18, no. 14, pp. 3955-3958, 2008.

[11] Y. Ogino, N. Ohtake, Y. Nagae et al., "Design, syntheses, and structure-activity relationships of novel NPY Y5 receptor antagonists: 2-3-Oxospiro[isobenzofuran- $1(3 \mathrm{H}), 4^{\prime}$-piperidin]1'-ylbenzimidazole derivatives," Bioorganic and Medicinal Chemistry Letters, vol. 18, no. 18, pp. 5010-5014, 2008.

[12] D. I. Shah, M. Sharma, Y. Bansal, G. Bansal, and M. Singh, "Angiotensin II-AT ${ }_{1}$ receptor antagonists: design, synthesis and evaluation of substituted carboxamido benzimidazole derivatives," European Journal of Medicinal Chemistry, vol. 43, no. 9, pp. 1808-1812, 2008.
[13] D. Belaziz, Y. Kandri Rodi, F. Ouazzani Chahdi, E. Essassi, M. Saadi, and L. E. Ammari, "1-Allyl-1H-1,3-benzimidazol-2(3H)one," Acta Crystallographica, vol. E68, article o3212, 2012.

[14] D. Belaziz, Y. Kandri Rodi, A. Kandri Rodi, E. M. Essassi, M. Saadi, and L. E. Ammari, "Ethyl 2-oxo-3-(3phthalimidopropyl)-2, 3-dihydro-1H-1, 3-benzimidazole-1carboxylate," Acta Crystallographica, vol. E69, pp. o641-o642, 2013.

[15] Y. Kandri Rodi, F. Ouazzani Chahdi, E. M. Essassi, S. V. Luis, M. Bolte, and L. El Ammari, "1,3-Dibenzyl-1H-benzimidazol2(3H)-one," Acta Crystallographica, vol. 67, no. 12, p. o3234, 2011.

[16] O. V. Dolomanov, L. J. Bourhis, R. J. Gildea, J. A. K. Howard, and H. Puschmann, "OLEX2: a complete structure solution, refinement and analysis program," Journal of Applied Crystallography, vol. 42, no. 2, pp. 339-341, 2009.

[17] G. M. Sheldrick, "a short history of SHELX," Acta Crystallographica, vol. A64, pp. 112-122, 2008.

[18] C. F. Macrae, I. J. Bruno, J. A. Chisholm et al., "Mercury CSD 2.0: new features for the visualization and investigation of crystal structures," Journal of Applied Crystallography, vol. 41, no. 2, pp. 466-470, 2008.

[19] L. L. C. Schrödinger, The PyMOL Molecular Graphics System, Version 1.3.

[20] B. J. Deppmeier, A. J. Driessen, T. S. Hehre et al., Spartan '08, build 132, Wavefunction, Irvine, Calif, USA, 2009. 

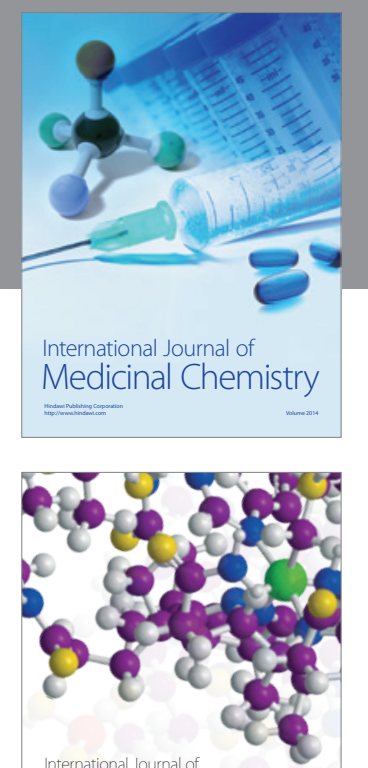

\section{Carbohydrate} Chemistry

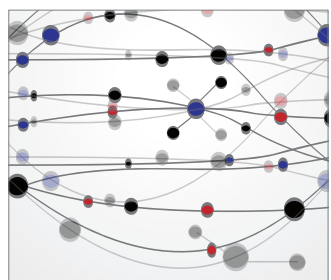

The Scientific World Journal
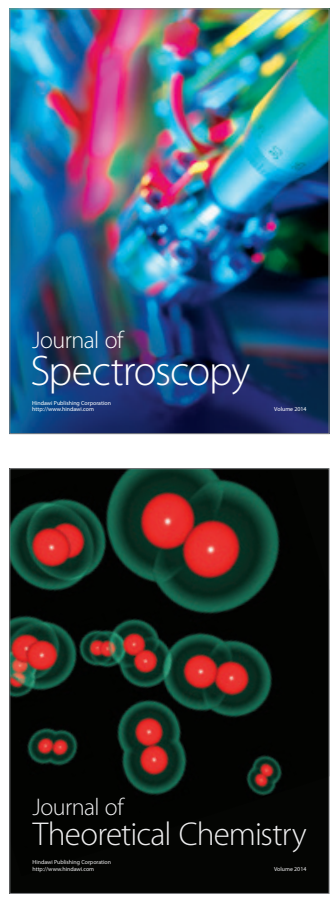
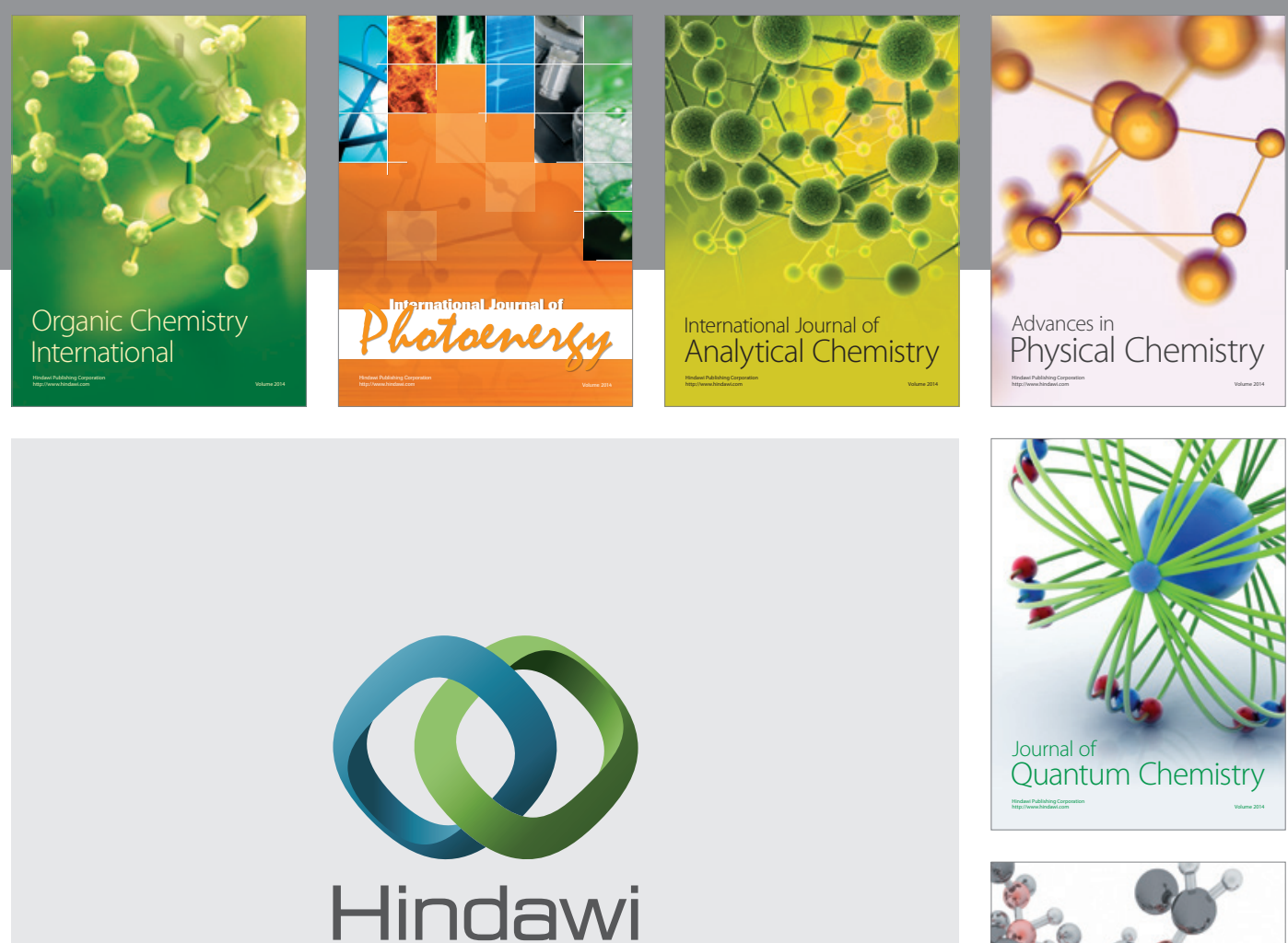

Submit your manuscripts at

http://www.hindawi.com

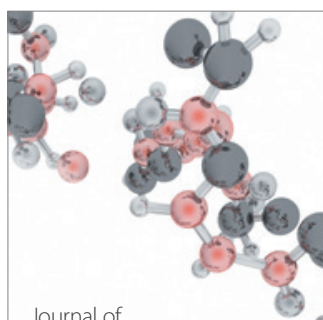

Analytical Methods

in Chemistry

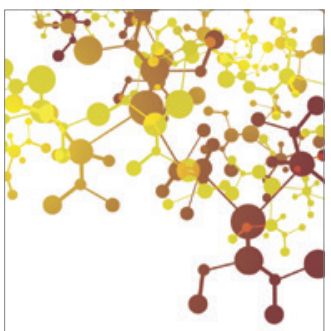

Journal of

Applied Chemistry

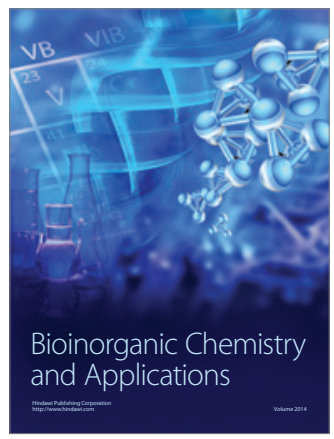

Inorganic Chemistry
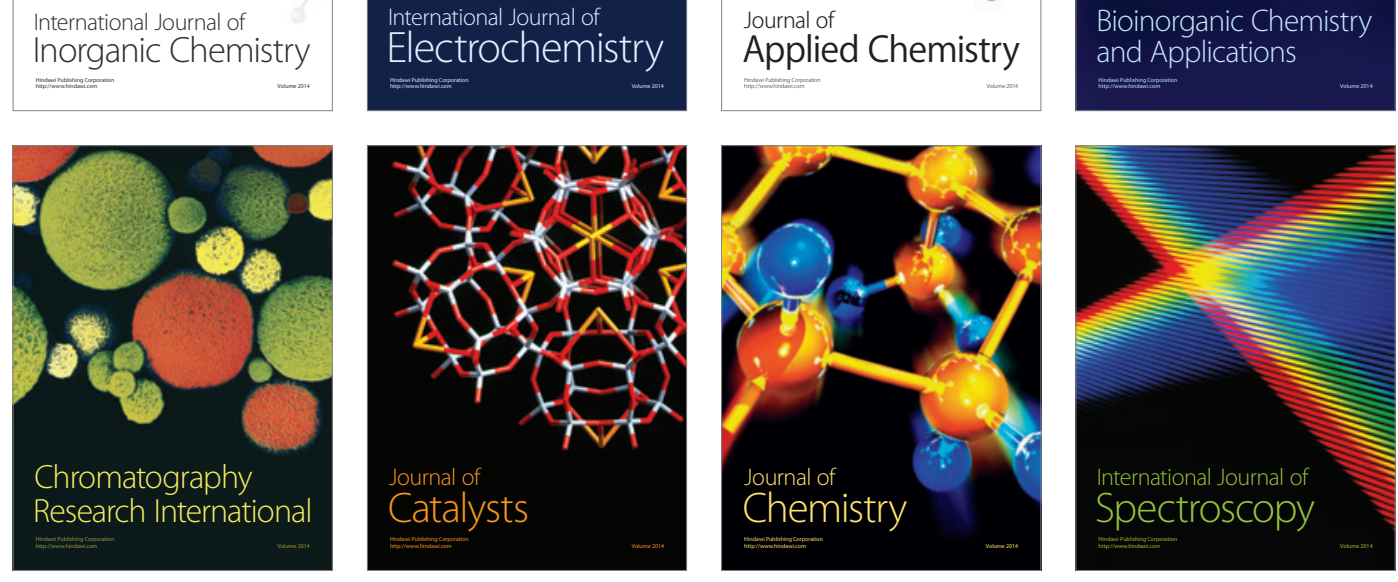